\title{
РАЗРАБОТКА ПРОЕКТА САНИТАРНО-ЗАЩИТНЫХ ЗОН С УЧЕТОМ ПОСЛЕДНИХ ИЗМЕНЕНИЙ ЗАКОНОДАТЕЛЬСТВА
}

\author{
Анастасия Алексеевна Кузнецова \\ Сибирский государственный университет геосистем и технологий, 630108, Россия, г. Новоси- \\ бирск, ул. Плахотного, 10, обучающийся, тел. (999)468-36-26, e-mail: nastyashe197@mail.ru
}

\section{Александр Викторович Чернов}

Сибирский государственный университет геосистем и технологий, 630108, Россия, г. Новосибирск, ул. Плахотного, 10, кандидат технических наук, доцент кафедры кадастра и территориального планирования, тел. (913)743-09-79, e-mail: avch-1011@mail.ru

В статье выполнен анализ актуального нормативно-правового обеспечения в области установления и учета санитарно-защитных зон, в том числе, с учетом изменений 2020 года. На основании последних изменений в законодательстве, предложены мероприятия для предприятий для внесения сведений в единый государственный реестр недвижимости, даны рекомендации по проведению санитарно-гигиенического контроля.

Ключевые слова: санитарно-защитная зона, хозяйствующий субъект, зона с особыми условиями использования территории, предельно допустимые выбросы, загрязняющие вещества

\section{TO THE QUESTION OF ESTABLISHING SANITARY-PROTECTIVE ZONES AND ENTERING THEIR BOUNDARIES IN THE UNIFIED STATE REAL ESTATE REGISTER}

\section{Anastasiya A. Kuznecova}

Siberian State University of Geosystems and Technologies, 10, Plakhotnogo St., Novosibirsk, 630108, Russia, Student, phone: (999)468-36-26, e-mail: nastyashe197@mail.ru

\section{Aleksandr V. Chernov}

Siberian State University of Geosystems and Technologies, 10, Plakhotnogo St., Novosibirsk, 630108, Russia, Ph. D., Associate Professor, Department of Cadastre and Territorial Planning, phone: (913)743-09-79, e-mail: avch-1011@mail.ru

The article analyzes the current regulatory framework in the field of establishing and accounting for sanitary protection zones, including, taking into account the changes in 2020. Based on the latest changes in legislation, measures have been proposed for enterprises to enter information into the unified state register of real estate, recommendations have been given for conducting sanitary and hygienic control.

Keywords: sanitary protection zone, economic entity, zone with special conditions for the use of the territory, maximum permissible emissions, pollutants

Актуальность данной темы обусловлена тем ,что предприятия, группы предприятий, их отдельные здания и сооружения с технологическими процессами, являющиеся источниками неблагоприятного влияния на среду обитания и здоровье человека, необходимо отделять от жилой застройки санитарно-защитными зонами, Федеральный закон № 455-Ф3 [1] внес изменения в Федеральный закон 
№ 342-Ф3 [2] , который, в свою очередь, изменил процедуру установления С33 как зон с особенными критериями использования территорий.

В представленной работе рассмотрим действующий порядок разработки проекта санитарно-защитных зон с учетом последних изменений в законодательстве.

Санитарно-защитная зона (С33) является не только линией градостроительного регулирования, но и целым комплексом прав, а также обязанностей хозяйствующего субъекта и населения. Главным видом С33 является ориентировочный, который обосновывается расчетами ожидаемого загрязнения и физического воздействия на атмосферный воздух, а также подтверждается результатами натурных наблюдений, но в данной работе мы выясним почему ориентировочные санитарно- защитные зоны прекращают свое существование.

В настоящее время проект С33 разрабатывается в согласовании с притязаниями:

- Правил установления санитарно-защитных зон и использования земельных участков, расположенных в границах санитарно-защитных зон, утвержденных Постановлением Правительства РФ от 03.03.2018 № 222 (в ред. от 21.12.2018; далее - Правила, Постановление № 222); [3]

- СанПиН 2.2.1/2.1.1.1200-03 «Санитарно-защитные зоны и санитарная классификация предприятий, сооружений и иных объектов» (далее - СанПиН 2.2.1/2.1.1.1200-03); [4]

- Градостроительного кодекса Российской Федерации (далее - ГрК РФ), т.к. СЗ3 признана ЗОУИТ, а порядок установления таких зон определен ГрК РФ. [5]

Согласно правилам впоследствии разработки проект С33 должен пройти экспертизу в уполномоченных органах и получить положительное санитарноэпидемиологическое заключение о соответствии санитарным нормам и правилам [6]. В случае если объект, для которого сконструирован и утвержден проект С33, находится на территории действующего промышленного узла аналогичного вида хозяйственной деятельности, необходимо провести исследования (измерения) атмосферного воздуха, уровней физического и (или) биологического воздействия на атмосферный воздух за контуром объекта.

Для корректного внесения границ С33 в единый государственный реестр недвижимости необходимо соблюдать выполнение ряда исследований для обоснования ее размера и местоположения:

- выполнение инвентаризации источников вредных выбросов на хозяйствующем субъекте и определение класса опасности;

- на источниках выделения вредностей необходимо контролирование соблюдения технологического режима работ, а на источниках выбросов необходимо систематически проводить контроль над выбросами с целью соблюдения утвержденных нормативов предельно-допустимых выбросов веществ в атмосферу;

- для санитарно-гигиенического контроля над показателями воздействия на окружающую среду необходимо проведение мониторинга по уровню загрязнения атмосферного воздуха, а также натурных измерений по шуму. 
Периодичность контроля загрязняющих веществ (азот оксид, сера диоксид, пыль меховая, аммиак) - в течение года, посезонно;

- проводить исследования уровня шума хозяйствующего субъекта.

Для получения заключения об установлении С33 правообладатель земельного участка представляет в Роспотребнадзор надлежащие бумаги: заявление об установлении С33, проект С33, экспертное заключение на проект С33, санитарно-эпидемиологическое заключение на проект С33, результаты измерений концентраций загрязняющих веществ и уровней физического и иных видов воздействия за контуром объекта (если объект действующий),файлы в xml-формате, содержащие текстовое и графическое описание границ С33, материалы оценки риска самочувствия населения (при необходимости) [7].

Сравнивая старую и новую редакции Федерального закона № 342-Ф3 и проанализируем, что изменилось в вопросе установления С33. Изменения, касающиеся СЗ3 как ЗОУИТ, начинаются с п. 13 ст. 26 Федерального закона № 342-Ф3 [8], который в действующей редакции предусматривает следующее:

- c 01.01.2022 (в предыдущей редакции - 01.01.2020) ориентировочные, расчетные (предварительные) С33 прекращают существование, а ограничения использования земельных участков в них не действуют [9];

- собственники зданий, сооружений, в отношении которых были определены ориентировочные, расчетные (предварительные) С33, до 01.10.2021 (в предыдущей редакции - 01.10.2019) обязаны обратиться в уполномоченные органы с заявлениями об установлении С33 или о прекращении существования ориентировочных, расчетных (предварительных) С33 с приложением документов, предусмотренных положением о С33 [10];

- органы государственной власти, органы местного самоуправления, а также правообладатели объектов недвижимости, расположенных полностью или частично в границах ориентировочных, расчетных (предварительных) С33, вправе обратиться в уполномоченные органы с заявлениями об установлении С33 или о прекращении существования ориентировочных, расчетных (предварительных) С33 с приложением необходимых документов;

- до дня установления С33 возмещение убытков, причиненных ограничением прав правообладателей объектов недвижимости в связи с определением до дня официального опубликования Федерального закона № 342-Ф3 (04.08.2018) ориентировочной, расчетной (предварительной) С33, выкуп объектов недвижимости, возмещение за прекращение прав на земельные участки в связи с невозможностью их использования в соответствии с разрешенным использованием не осуществляются [11].

Как видим, границы С33, определенные по старым требованиям закона, так называемые ориентировочные, расчетные (предварительные) С33 - теперь действуют до начала 2022 г.

Проанализировав изменения можно сделать вывод о том, что прекратят свое существование предварительные санитарно-защитные зоны (С33), что снимет ограничения на использование многих земельных участков. Новейший реестр 
будет сформирован только к 2025 году. Это означает, что на картах возникнут «слепые зоны» - участки, где формально можно строить, но есть опасность в будущем попасть под санкции. Нарушение законодательства в области обеспечения санитарно-эпидемиологического благополучия населения, выразившееся в нарушении действующих санитарных правил и гигиенических нормативов, невыполнении санитарно-гигиенических и противоэпидемических мероприятий, влечет предупреждение или наложение административного штрафа на юридических лиц - от десяти тысяч до двадцати тысяч рублей или административное приостановление деятельности на срок до девяноста суток. Так установление С33 для автомобильных и железных дорог становится главной проблемой и камнем преткновения. Уже сейчас известно о протесте, высказанном ОАО «РЖД», так как необходимы большие денежные ресурсы на установление С33 для всех железных дорог. По мнению участников рынка, пока все зоны с особыми условиями использования территорий (ЗОУИТ) не будут занесены в Единый государственный реестр недвижимости, компании не смогут провести реальную оценку стоимости и окупаемости земель [12].

Между тем так называемые промзоны имеют все шансы для развития территорий, которые сегодня остаются фактически бесхозными и портят облик города. Законодательно установлена возможность третьим лицам инициировать сокращение С33. На практике этот процесс очень долгий и также не обходится без участия собственника опасного предприятия. За счет уменьшения СЗЗ можно освободить десятки и даже сотни гектаров земель. При этом, по данным риелторов, спрос на жилье, построенное вблизи промышленных объектов, пользуется большим спросом у коммерсантов. Мы видим, что сегодня жители городов готовы рассмотреть такие объекты, особенно если компании предлагают заманчивые планировки и хорошие цены, вследствие этого предприятиям необходимо в срок до 2022 г. провести исследования и, если необходимо - установить С33 и внести данные в ЕГРН.

\section{БИБЛИОГРАФИЧЕСКИЙ СПИСОК}

1. Федеральный закон «Об охране атмосферного воздуха» [Электронный ресурс] : от 27.12.2019 N 455-ФЗ последняя редакция. - Доступ из справ.-правовой системы «КонсультантПлюс».

2. Федеральный закон «О внесении изменений в Градостроительный кодекс Российской Федерации и отдельные законодательные акты Российской Федерации» [Электронный ресурс] : от 03.08.2018 N 342-Ф3 последняя редакция. - Доступ из справ. -правовой системы «КонсультантПлюс».

3. Гиниятов, И. А. Система показателей информационной модели мониторинга земель сельскохозяйственного назначения [Текст] / А.Л. Ильиных - Информационные технологии, системы и приборы в АПК. Ч.1: материалы 6-ой Междунар. научно-практич. конференции "АГРОИНФО-2015" (Новосибирск, 22-23 октября 2015 г.) / Сибирский физико-технический институт аграрных проблем. - Новосибирск, 2015. - С. 390 - 394.

4. Федеральный закон «О внесении изменений в Земельный кодекс Российской Федерации и отдельные законодательные акты Российской Федерации» [Электронный ресурс] : от 13.07.2015 № 252-ФЗ. - Доступ из справ. - правовой системы «КонсультантПлюс». 
5. Майоров, Е.Г. Порядок установления и внесения в ЕГРН границ территориальных зон на примере Р.П. Краснозерское Новосибирской области [Текст] /Е.Г. Майоров, Е.С. Плахова, Н.О. Митрофанова, // Интерэкспо ГЕО-Сибирь-2019. XV Междунар. науч. конгр. : . Междунар. науч.-технолог. конф. студентов и молодых ученых «Молодежь. Инновации. Технологиии: сб. материалов в 9 т. (Новосибирск, 24-26 апреля 2019 г.). Новосибирск: СГУГиТ, 2019. Т. 7. С. 239-245.

6. Федеральный закон «О государственной регистрации недвижимости» [Электронный ресурс] : от 13.07.2015 N 218-Ф3 последняя редакция.- Доступ из справ.-правовой системы «КонсультантПлюс».

7. Волгина, А.С. Основные источники сведений для ведения Единого государственного реестра недвижимости [Текст] /А.С. Волгина, А.В. Шамилов, Н.О. Митрофанова, // Интерэкспо ГЕО-Сибирь-2019. XV Междунар. науч. конгр. : . Междунар. науч.-технолог. конф. студентов и молодых ученых «Молодежь. Инновации. Технологии»: сб. материалов в 9 т. (Новосибирск, 24-26 апреля 2019 г.). Новосибирск: СГУГиТ, 2019. Т. 7. С. 146-157.

8. Федеральный закон «О санитарно-эпидемиологическом благополучии населения» [Электронный ресурс] : от 30.03.1999 N 52-ФЗ ред. от 26.07.2019. - Доступ из справ.-правовой системы «КонсультантПлюс».

9. Ильиных, А. Л. К вопросу о классификации факторов, влияющих на эффективность сельскохозяйственного землепользования [Текст] / И. А. Гиниятов - Интерэкспо ГЕО-Сибирь2017. XIII Междунар. науч. конгр., 17-21 апреля 2017 г., Новосибирск : Междунар. науч. конф. «Экономическое развитие Сибири и Дальнего Востока. Экономика природопользования, землеустройство, лесоустройство, управление недвижимостью» : сб. материалов в 2 т. Т. 2. - Новосибирск : СГУГиТ, 2017. - С. 139-143.

10. Троценко, Е.С. Современное состояние мониторинга земель сельскохозяйственного назначения Российской Федерации [Текст] / Е.С. Троценко - В сб. : Интерэкспо ГЕО-Сибирь. 2018. T. 2. № 3. C. 85-89.

11. Троценко, Е.С. Элементы структурного геоинформационного обеспечения агроэкологического адаптивно-ландшафтного землепользования [Текст] / Н.И. Добротворская, А.В. Дубровский, С.Ю. Капустянчик, О.И. Малыгина - Известия высших учебных заведений. Геодезия и аэрофотосъемка. 2014. № S4. С. 146-153.

12. Санитарно-защитные зоны и санитарная классификация предприятий, сооружений и иных объектов [Электронный ресурс] : СанПиН 2.2.1/2.1.1.1200-03. - Доступ из справ. правовой системы «КонсультантПлюс». 